Cambridge University Press

0521842530 - Family, Kinship, and Sympathy in Nineteenth-Century American Literature

Cindy Weinstein

Frontmatter

More information

\title{
FAMILY, KINSHIP, AND SYMPATHY IN NINETEENTH-CENTURY AMERICAN LITERATURE
}

In Family, Kinship, and Sympathy in Nineteenth-Century American Literature Cindy Weinstein radically revises our understanding of nineteenth-century sentimental literature in the United States. She argues that these novels are far more complex than critics have suggested, expanding the canon of sentimental novels to include some of the more popular, though under-examined writers, such as Mary Jane Holmes, Caroline Lee Hentz, and Mary Hayden Green Pike. Rather than confirming the power of the bourgeois family, Weinstein argues, sentimental fictions used the destruction of the biological family as an opportunity to reconfigure the family in terms of love rather than consanguinity. Their texts intervened in debates about slavery, domestic reform, and other social issues of the time. Furthermore, Weinstein shows how canonical texts, such as Melville's Pierre and works by Stowe and Twain, can take on new meaning when read in the context of nineteenth-century sentimental fictions. Through intensive close readings of a wide range of novels, this groundbreaking study demonstrates the aesthetic and political complexities of this important and influential genre.

CINDY WeInSTeIn is Associate Professor of English at the California Institute of Technology. She is the author of The Literature of Labor and the Labors of Literature: Allegory in Nineteenth-Century American Fiction (Cambridge, 1995) and the editor of The Cambridge Companion to Harriet Beecher Stowe (Cambridge, 2004). 
Cambridge University Press

0521842530 - Family, Kinship, and Sympathy in Nineteenth-Century American Literature

Cindy Weinstein

Frontmatter

More information

CAMBRIDGE STUDIES IN AMERICAN LITERATURE AND CULTURE

\section{Editor}

Ross Posnock, New York University

Founding Editor

Albert Gelpi, Stanford University

\section{Advisory Board}

Sacvan Bercovitch, Harvard University

Ronald Bush, St. John's College, Oxford University

Wai Chee Dimock, Yale University

Albert Gelpi, Stanford University

Gordon Hutner, University of Kentucky

Walter Benn Michaels, University of Illinois, Chicago

Kenneth Warren, University of Chicago

Recent books in this series

I47. CINDY WEINSTEIN

Family, Kinship, and Sympathy in Nineteenth-Century American Literature

I46. ELIZABETH HEWITT

Correspondence and American Literature, 1770-1865

I45. ANNA BRICKHOUSE

Transamerican Literary Relations and the Nineteenth-Century Public

Sphere

I44. ELIZA RICHARDS

Gender and the Poetics of Reception in Poe's Circle

I43. JENNIE A. KASSANOFF

Edith Wharton and the Politics of Race

I47. JOHN MCWILLIAMS

New England's Crises and Cultural Memory: Literature, Politics, History,

Religion, 1620-1860

I4I. SUSAN M. GRIFFIN

Anti-Catholicism and Nineteenth-Century Fiction

I4O. ROBERT E. ABRAMS

Landscape and Ideology in American Renaissance Literature 
Cambridge University Press

0521842530 - Family, Kinship, and Sympathy in Nineteenth-Century American Literature

Cindy Weinstein

Frontmatter

More information

\title{
FAMILY, KINSHIP, AND SYMPATHY IN NINETEENTH-CENTURY AMERICAN LITERATURE
}

\author{
CINDY WEINSTEIN \\ Associate Professor of English, California Institute of Technology
}


Cambridge University Press

0521842530 - Family, Kinship, and Sympathy in Nineteenth-Century American

Literature

Cindy Weinstein

Frontmatter

More information

PUBLISHED BY THE PRESS SYNDICATE OF THE UNIVERSITY OF CAMBRIDGE

The Pitt Building, Trumpington Street, Cambridge CB2 IRP, United Kingdom

CAMBRIDGE UNIVERSITY PRESS

The Edinburgh Building, Cambridge, CB2 2RU, UK

40 West 2oth Street, New York, NY IOOII-42II, USA

477 Williamstown Road, Port Melbourne, VIC 3207, Australia

Ruiz de Alarcón I3, 280I4 Madrid, Spain

Dock House, The Waterfront, Cape Town 8ooI, South Africa

http://www.cambridge.org

C) Cindy Weinstein 2004

This book is in copyright. Subject to statutory exception and to the provisions of relevant collective licensing agreements,

no reproduction of any part may take place without

the written permission of Cambridge University Press.

First published 2004

Printed in the United Kingdom at the University Press, Cambridge

Typeset in II/I2.5pt Adobe Garamond [PND]

A catalogue record for this book is available from the British Library

Library of Congress Cataloguing in Publication data

Weinstein, Cindy.

Family, kinship, and sympathy in nineteenth-century American literature / Cindy Weinstein.

p. $\quad \mathrm{cm}$. - (Cambridge studies in American literature and culture; I47)

Includes bibliographical references and index.

ISBN O 52I 84253 o (hardback)

I. American fiction - I9th century - History and criticism. 2. Domestic fiction, American - History and criticism. 3. Literature and society - United States - History - 19th century. 4. Sympathy in

literature. 5. Kinship in literature. 6. Family in literature. I. Title. II. Series.

\footnotetext{
PS374.D57W45 2004

$8 \mathrm{I} 3^{\prime} \cdot 3093552-\mathrm{dc22} \quad 2004045923$

ISBN O 52I 84253 o hardback
} 
Cambridge University Press

0521842530 - Family, Kinship, and Sympathy in Nineteenth-Century American Literature

Cindy Weinstein

Frontmatter

More information

For Jim, Sarah, and Sam 
Cambridge University Press

0521842530 - Family, Kinship, and Sympathy in Nineteenth-Century American Literature

Cindy Weinstein

Frontmatter

More information

\section{Contents}

Acknowledgments

Introduction

I In loco parentis

2 "A sort of adopted daughter": family relations in The Lamplighter

3 Thinking through sympathy: Kemble, Hentz, and Stowe

4 Behind the scenes of sentimental novels: Ida May and Twelve Years a Slave

5 Love American style: The Wide, Wide World 130

6 We are family, or Melville's Pierre $\quad 159$

Afterword

Notes

Select bibliography

Index 
Cambridge University Press

0521842530 - Family, Kinship, and Sympathy in Nineteenth-Century American Literature

Cindy Weinstein

Frontmatter

More information

\section{Acknowledgments}

So many people have my profound gratitude that it's difficult to know where to begin. Eric Sundquist and Michael Gilmore have given me the kind of support and critique of which academics dream. They are models of discipline and generosity. Dorothy Hale's intellectual guidance and personal friendship have always inspired me to do the best work possible and have sustained me for many years and over many miles. I am grateful to Jim Astorga, Martha Banta, Sara Blair, Gregg Crane, William Merrill Decker, Wai Chee Dimock, Emory Elliott, Jonathan Freedman, Jane Garrity, Greg Jackson, Jeffrey Knapp, Robert Levine, Lori Merish, Nancy Ruttenberg, Margit Stange, John Sutherland, Lynn Wardley, and Arlene Zuckerberg, all of whom have spent time with this book and have contributed invaluable advice. Marianne Noble, Lois Brown, Xiamora Santamartin, and Mary Kelley intervened at especially helpful moments. For reading the manuscript with great care and attentiveness, I am deeply indebted to Carolyn Karcher and to Samuel Otter. Special thanks go to Sam, whose generosity of spirit and suggestion is unsurpassed. Thank you to Ross Posnock, head of the Cambridge series, and Ray Ryan, editor of the series, for finding such ideal readers and for so graciously shepherding the manuscript into print. I am also grateful to Jackie Warren, Lucy Carolan, and Mike Leach at Cambridge University Press. Thank you to my colleagues at Caltech, John Brewer, Moti Feingold, Kevin Gilmartin, Cathy Jurca, Morgan Kousser, Jenijoy Labelle, and Mac Pigman. Special thanks to Cathy, whose keen and generous readings of early versions of chapters helped me to clarify the argument. I am grateful for permission to reprint Chapter 2, "'A Sort of Adopted Daughter': Family Relations in The Lamplighter," which first appeared in ELH 68 (200I): IO23-IO47. My thanks also go to the staff of the Huntington Library and Alan Jutzi, in particular. The division of humanities and social sciences, under the direction of John Ledyard, gave me the time to write this book, and Jean Ensminger provided the additional support to finish it. 
Cambridge University Press

0521842530 - Family, Kinship, and Sympathy in Nineteenth-Century American Literature

Cindy Weinstein

Frontmatter

More information

$\mathrm{X}$

Acknowledgments

Susan Davis, Megan Guichard, Margaret Lindstrom, Gina Morea, the Inter-Library Loan staff at Caltech, and Peet's coffee facilitated all matters related to this project.

I began to have the idea for this book when my father was in the later stages of Alzheimer's disease. Although the illness took away his mind, he somehow managed never to let it take away his heart. His abiding love helped me to write this book. For my mother's support and affection, I am deeply grateful. Thank you to my sister, Linda, who found my family a house to live in during our wonderful sabbatical year in Maryland, where most of the book was written, and to my brother, Lyle, for providing comfort, humor, affection, and encouragement on a constant basis. This book is dedicated to my husband, Jim, and our children, Sarah and Sam, whose love makes all things imaginable and possible. 